\title{
Recent Active Fires under El Niño Conditions in Kalimantan, Indonesia
}

\author{
Nina Yulianti*, Hiroshi Hayasaka \\ Graduate School of Engineering, Hokkaido University, Sapporo, Japan. \\ Email: Nina@eng.hokudai.ac.jp \\ Received January $10^{\text {th }}, 2013$; revised February $11^{\text {th }}, 2013$; accepted February $25^{\text {th }}, 2013$
}

\begin{abstract}
Analysis of the most recent 10-year periods (2002 to 2011) of MODIS hotspots data (fires) and precipitation in Palangkaraya and Pontianak was carried out to identify seasonal and spatial fire occurrence in Kalimantan under El Niño conditions, and to asses future forest condition in Kalimantan. Most data was tallied every 10-day to analyze seasonal and spatial fire occurrence. Seasonal and spatial analysis results for severe fire years, namely 2006 and 2009, under El Niño conditions were as follows: the severest fire incidents for whole Kalimantan occurred in October in 2006 under the driest conditions in both Palangkaraya and Pontianak. The severest fires for the Mega Rice Project (MRP) area and its vicinity occurred in late September in 2009 under the driest conditions for Palangkaraya. Fire activities in the last 10-year in south Central Kalimantan were severe than other areas in Kalimantan. This may be explained by different dry conditions of peat. Namely, the peat in the southern part of Central Kalimantan could become dryer under the relatively longer dry season (about 3-month) compared with other areas (dry season in West Kalimantan is only 2/3-month). One of spatial analysis results clearly showed a so-called a fire belt shape arising from severe fires that occurred mainly on the southern coastal peatlands from West to Central Kalimantan in mid October in 2006.
\end{abstract}

Keywords: Dry Season; El Niño; MODIS Hotspot; MRP; Peat Fire

\section{Introduction}

Fires in tropical forest and peat areas in Indonesia are not a new phenomenon, but have repeatedly occurred since about 13,200 BC [1]. Recently, Kalimantan has suffered from repeated fires, especially under El Niño conditions, as studied by Fuller et al. (2006) [2] and Wooster et al. (2012) [3]. This change in fire incidence in Kalimantan may be related to the rapid deforestation rate due to logging, developments such as palm oil plantation, and the famous MRP. The total forest area for Kalimantan was $414,700 \mathrm{~km}^{2}$ in late 1960s [4] but had decreased to $248,450 \mathrm{~km}^{2}$ by $2009 / 2010$ [5]. Thus, forest loss in Kalimantan during these 40 years was $40 \%$ of the total original forested area. The average annual deforestation rate in 2000 was $1.3 \%$ in Kalimantan Island [6].

Most fires in Kalimantan are caused by humans, much like other fires in Indonesia. Once these human-caused fires have started, the fire behavior is controlled by natural factors such as precipitation, wind and dryness of fuel. For most tropical areas in Southeast Asia, including Kalimantan with its relatively high annual rainfall, precipitation is one of most effective factors against fire. Indeed, our earlier study [7] showed that more than $90 \%$ of peat

${ }^{*}$ Corresponding author. fires in Central Kalimantan from 1997 to 2007 occurred in the dry season. Secondly, fires on peatland are greatly controlled by the ground water level (GWL). Under low GWL condition, dried bare peat becomes most flammable materials. Because dried peat is a solid akin to a low-grade coal [8] and covers forest floor with relatively high spatial density compared to dominant vegetation types such as ferns and local trees [9] with lower spatial density compared with these peats.

Around $30,951 \mathrm{~km}^{2}$ or $20 \%$ of the area of Central Kalimantan is peatland [10], and most of this area remained pristine up to the beginning of the 1990s [11]. In 1996, the Indonesian Government initiated the MRP to develop a million hectares of rice fields in the tropical swampforest between the Sebangau and Barito rivers in Central Kalimantan. More than $63 \%\left(9191 \mathrm{~km}^{2}\right)$ of the total MRP area was peatland [12]. After the MRP ended in 1999, vast drained peatland areas were left and serious peat fires common during every dry season.

To ascertain the relationships between fire activity and various weather conditions, we attempted to obtain weather data from several weather stations in Kalimantan. However, we could not obtain data, except for Palangkaraya and Pontianak. Thus, we have to use only daily 
precipitation data measured at two airport weather stations, one in Palangkaraya (Central Kalimantan) and the other in Pontianak (West Kalimantan). Unfortunately, precipitation data in Pontianak was only available from 2001 to 2010, still with some missing data. Fortunately, recent studies $[13,14]$ have shown precipitation patterns in two regions of Kalimantan. Only the northern part of West Kalimantan had a pattern of two dry seasons, affected by two monsoons, or northeast and southeast monsoon. Meanwhile, Palangkaraya had a pattern of one dry season like other most parts of Indonesia. Weather data from Palangkaraya contained fundamental weather information from 1978; not only precipitation but also temperature, wind direction and speed, and humidity.

To evaluate the fire situation in Kalimantan accurately, satellite monitoring is the best method. JICA (Japan International Cooperation Agency) started to collect hotspot data using NOAA (National Ocean and Atmosphere Administration) sensor from July 1997 [15]. However, NOAA covers only the western part of Indonesia, and there is some missing data from recent years. MODIS (Moderate Resolution Imaging Spectroradiometer) has been collecting hotspot data since 2002 and has therefore accumulated more than 10-year of data. Analysis of MODIS data has already been used to identify Asian vegetation fire trends, fire statistics of individual countries, and monthly fire occurrence [16]. Fire regimes in 2008/2009 in South East Asia peatlands were analyzed by Miettinen et al. (2011) [6]. In a previous paper, we also used MODIS hotspot data of one-degree cells to identify forest and peat fire trends in Indonesia [17]. The spatio-temporal fire occurrence trend until mid-2000s in Kalimantan has been investigated by Langner and Siegert (2009) [18]. Our research group [7] also analyzed peat fire activity in the MRP area and found the relationship between precipitation, Niño 3.4 SST anomalies, ground water level, and peat fire occurrence in the MRP area.

In this study, we carefully analyzed seasonal and spatial fire occurrences using the above-mentioned 10-year of MODIS hotspots (fire) and precipitation data in Palangkaraya and Pontianak. We attempted to determine the seasonal and spatial trends of fire occurrence under El Niño conditions in Kalimantan. Analysis of seasonal fire occurrence was carried out using hotspot and precipitation data at 10-day intervals during fire season from early June to late October. For analysis of spatial fire occurrence, fire (hotspot) distribution maps were drawn at 10-day intervals to identify active fire areas in Kalimantan.

From these analyses, we may infer MRP was carried out in the worst location in terms of the climate increasing the fire risk. In other words, peat in Central Kalimantan could easily become dried peat during the relatively long dry season (3-month). Another analysis re- vealed the existence of pre-dry season (caution) fires before the occurrence of severe fires. Thus, we propose a method for forecasting and preventing future fires using only three items; (1) observation of caution fire occurrence by MODIS, (2) assessment of the drought condition using the accumulated precipitation curve form around early June, and (3) El Niño information from NOAA.

\section{Methodology}

\subsection{Study Area and Peatland}

The study area covered the Indonesian territory of Kalimantan from about $4.5^{\circ} \mathrm{N}$ to $4.5^{\circ} \mathrm{S}$ and from about $108.5^{\circ} \mathrm{E}$ to $118.5^{\circ} \mathrm{E}$ (Figure 1). The total land area of Kalimantan is about $586,000 \mathrm{~km}^{2}$ ( $70 \%$ of Borneo Island; [19]). Kalimantan is politically divided into four provinces, namely West, Central, South, and East Kalimantan. East Kalimantan has the largest land area of 245,000 $\mathrm{km}^{2}$ (42\% of the area of Indonesian Kalimantan). Land areas for Central, West, and South are 157,000 (27\%), 146,000 (25\%), and $36,000 \mathrm{~km}^{2}(6 \%)$, respectively. Presently, the tropical forest, which partially overlaps the peat swamp forest, still covers nearly half of Kalimantan $(\sim 240,000$ $\mathrm{km}^{2}$ (41\%); [5]).

Distribution of peatland is shown in Figure 1. From Figure 1, it can be seen that coastal areas in Kalimantan, especially in West and Central Kalimantan, are mainly composed of so-called coastal peatland. Coastal peatland is distributed from the northern area of Singkawang in West Kalimantan to the MRP area near Banjarmasin in South Kalimantan. East Kalimantan also has a large

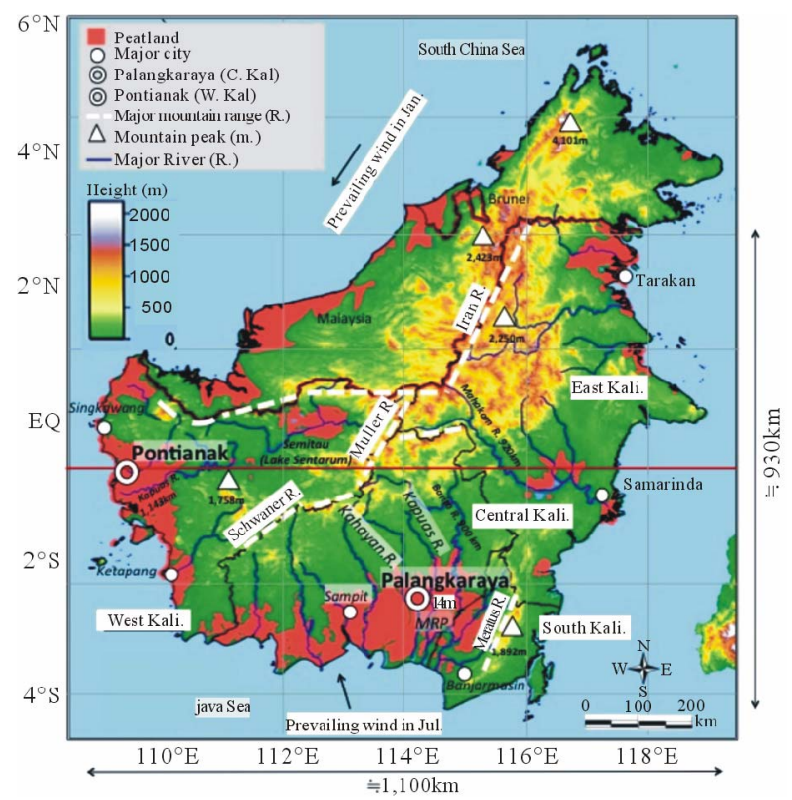

Figure 1. Distribution of peatland, mountainous regions, prevailing wind directions and expected climate zone boundaries in Kalimantan. 
coastal peatland near Tarakan. Two large interior peatlands, independent from the coast, are located near Semitau (Lake Sentarum) in the interior area of West Kalimantan and the west side area of Samarinda in East Kalimantan. The total area of peatlands in Kalimantan is about $57,000 \mathrm{~km}^{2}$ (about $10 \%$ of the land area of Kalimantan; [20]) and larger than the land area of South Kalimantan province.

Approximate positions of major rivers are also drawn in Figure 1 to show their relationships with the peatlands. Most of the peatlands in Kalimantan were made from the accumulation of soil organic matter (peat) during the Holocene era [21]. Tropical swamp forests are distributed on these peatlands thanks to rivers transporting not only water but also nutrients from mountainous areas. Thus, Great Kahayan and Kapuas River in Central Kalimantan could nourish a large area of tropical swamp forests in MRP and its surrounding area. However, after deforestation and land development such as MRP in such a tropical swamp forest, fires could become some what more severe due to drainage or bared dry peat soil. The altitude of peatland near Palangkaraya is only $14 \mathrm{~m}$ and its distance from the nearest coast is $100 \mathrm{~km}$, as shown in Figure 1.

Under very flat geographical conditions, very thick peat layers (deeper than $10 \mathrm{~m}$ at peat dome) in MRP areas were formed in places over a long period time [22]. Nowadays, flat condition will make fire very likely. In other words, irrigation canals from major rivers could not provide sufficient water to MRP areas due to lower river water level when drought condition occur. Namely, once drought started, vast dried peatland will be made in MRP under low ground water level condition because irrigation canals worked as drainage canals. It will lead to severe peat fire occurrence. Thus, recent frequent peat fires in MRP area (about 5 Giga tons of peat carbon) become one of big issue for the world environmental.

\subsection{Weather and Precipitation Data}

The climate zone of Kalimantan Island is "tropical wet" [4] and fires are usually suppressed by heavy rainfall. However, the El Niño event usually brings drought conditions to Kalimantan. Drought conditions in Kalimantan vary from place to place. Kalimantan is not a small island, but rather the third largest island in the world with a size is of about $1100 \mathrm{~km}$ from east to west and about $1300 \mathrm{~km}$ from north to south. A previous study on precipitation in South East Asia [13,14] showed some precipitation patterns in Kalimantan Island. In this paper, two precipitation patterns were derived from weather data measured at Palangkaraya (Central Kalimantan) and Pontianak (West Kalimantan), and used to explain fire occurrence in both areas (see Figure 1). The precipitation patterns in other areas were inferred by considering topography effects, weather, and fire history. In Figure 1, major mountain ridges are shown by dotted lines, and the prevailing wind directions in July and January are shown by arrowed lines. In this paper, we do not discuss fire activity in East Kalimantan due to the low number of hotspots. However, we hypothesize that weak fire activeity in East Kalimantan may be due to mountain effects or higher rainfall.

Precipitation data for the MRP+ area (Central Kalimantan) was extracted from full weather data measured at Palangkaraya Airport (Tjilik Riwut, $2.23^{\circ} \mathrm{S}, 113.95^{\circ} \mathrm{E}$ ), which is about $100 \mathrm{~km}$ from the nearest coast-line (see Figure 1). The mean precipitation from the 34 years from 1978 to 2011 was used to ascertain the dry season period. The last 10 years of mean precipitation data, from 2002 to 2011, were used to show recent precipitation trends and their relation to fire occurrence.

Precipitation data measured at Pontianak Airport (Siantan Climatology Station, $0.15^{\circ} \mathrm{S}, 109.40^{\circ} \mathrm{E}$ ), located about $25 \mathrm{~km}$ from the nearest coast-line (see Figure 1), are used for the northern part of West Kalimantan. Nine years of mean precipitation data from 2001 to 2010 (excluding 2003 due to 5 months missing data) were used to show the dry season period, recent precipitation tendency, and their relations to fire. Both stations located in West and Central Kalimantan are under the authority of Indonesia Meteorological, Climatology and Geophysical Agency (BMKG).

Daily precipitation data were processed to determine the average daily precipitation data for certain periods and the accumulated precipitation data from an arbitrary date. In this paper, a 10-day period was used to evaluate the average daily precipitation and day number (DN for short here after) 150 was used as an arbitrary date or starting date for accumulated precipitation. This data processing was applied for simplicity instead of other data smoothing methods. By using a 10-day period, we could identify the season more easily than DN. Expressions such as early June, mid August, late September are used in this paper instead of $\mathrm{DN}=150$ to 159 . In addition, accumulated precipitation data for every 10-day is simply converted to mean daily precipitation ( $\mathrm{mm} /$ day).

\subsection{MODIS Hotspot Data and Grid Analysis}

Personally provided daily MODIS hotspot data (Collection 5.1 active fire product) for 2002 to 2011 were used in this paper. Recently, MODIS data has been extracted automatically through the FIRMS website (Fire Information for Resources Management System, https://earthdata.nasa.gov/data/near-real-time-data/firms). The total amount of 10-year hotspot data for Kalimantan, including a small part of Malaysia, reached 244,692 hotspots.

In this paper, several cell sizes were used in the analy- 
sis, all utilizing latitudes and longitudes as the basis for the grid used to identify the locations across Kalimantan. Cell sizes with side lengths from 0.5 to 0.01 degrees were used. For simplicity, the cell side lengths were based on latitude and longitude, meaning that the area of cells differs depending on latitude. Most of the analysis used a grid cell size of $0.5^{\circ}$ in longitude and latitude to evaluate hotspot density and fire distribution in Kalimantan. Hotspots were tallied depending on their longitude and latitude. A hotspot density measurement of "hotspots/cell" was introduced for simple comparison. Conversion to a more exact and universal measurement of "hotspots $/ \mathrm{km}^{2}$ " should be carried out using the length of the $0.5^{\circ}$ grid at various latitudes. However, there is not much difference in the areas of $0.5^{\circ}$ grid cells located within $0^{\circ} \pm 4.5^{\circ}$ latitude. The approximate area of these grid cells at the equator, to be used in the conversion, is $3070 \mathrm{~km}^{2}$.

\section{Results and Discussions}

\subsection{Dry Season}

In total, 35 accumulated precipitation data points for each year, one for every 10-day interval, were made to identify dry season in this paper. Each precipitation data point was placed at its representative point, such as DN 5, 15, 25, as shown in Figures 2 and $\mathbf{3}$ with a starting period of $\mathrm{DN}=1$ to 9 . This data processing (every 10-day interval) was also effective to find fire occurrence before the dry season, because there were not so many daily hotspots at this time. The accumulated precipition curve derived from accumulated precipitation data was also very useful for recognizing drought conditions.

\subsubsection{Dry Season in Palangkaraya, Central Kalimantan}

In Figure 2, the daily mean precipitation of two different

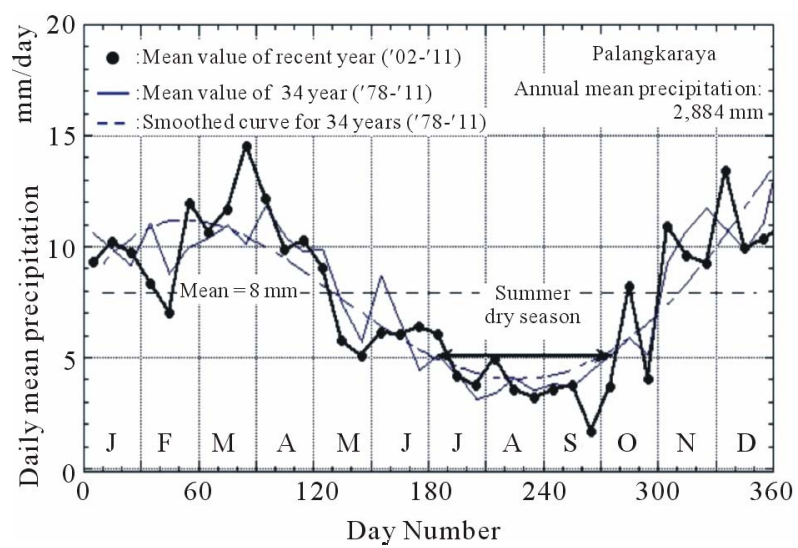

Figure 2. Daily mean precipitation patterns using 10- and 34-year data from Palangkaraya, Central Kalimantan.

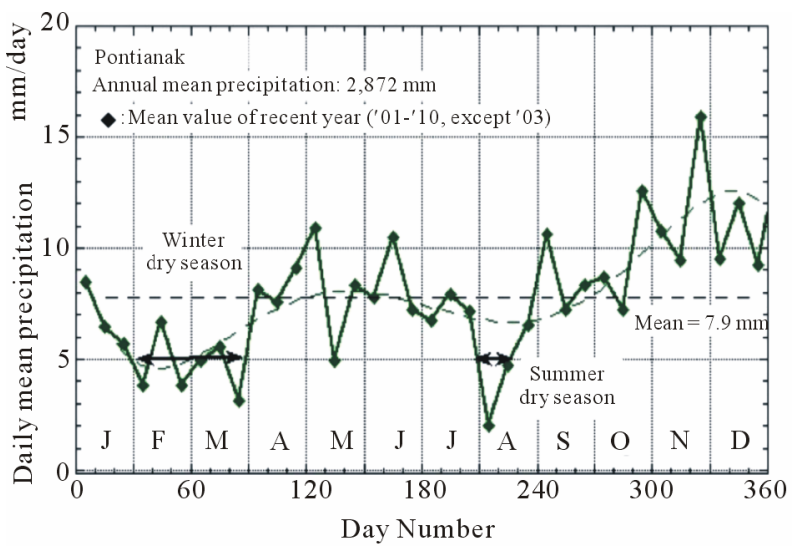

Figure 3. Daily mean precipitation patterns using 9-year data in in Pontianak, West Kalimantan.

periods are plotted with thick and thin solid lines. The thick line with a solid round mark shows the seasonal change of daily mean precipitation in the recent years of 2002 to 2011. Daily mean precipitation for the recent 10-year interval from 2002 to 2011 was $7.88 \mathrm{~mm} /$ day. The thin line shows the seasonal variation of daily mean precipitation for the 34-year period from 1978 to 2011. The 34-year daily mean precipitation is $7.98 \mathrm{~mm} /$ day. A smaller value in the daily mean precipitation for the recent 10-year interval implies dryer conditions in recent years. One more curve with a dotted line in Figure 2 is a simple smoothed curve for the daily mean precipitation from the 34-year data, and was used to define the dry season.

In this paper, a daily mean precipitation of $5 \mathrm{~mm} /$ day was temporally used as a threshold value to define the dry season in Palangkaraya. With this threshold value, the dry season period in Palangkaraya was defined as the 3-months from early July to late September, using the smoothed curve for the 34-year data, as shown in Figure 2. This period coincided with the period with the lowest under ground water level [23]. However, there was about one and half month time lag between the lowest value of precipitation at $\mathrm{DN}=230$ and the lowest under ground water level at $\mathrm{DN}=275$. Recent fire activity tended to show a fire peak at around $\mathrm{DN}=275$. Very low daily mean precipitation $(1.52 \mathrm{~mm} /$ day $)$ in late September was the lowest daily mean precipitation of the last 34-year. This recent precipitation trend could also support active fires in recent decades.

\subsubsection{Dry Season in Pontianak, West Kalimantan}

In Figure 3, daily mean precipitation in Pontianak from 2001 to 2010 (except 2003 due to data missing) are shown with a thick line with solid diamond symbols. A dotted thin line in Figure 3 was a simple smoothed curve for daily mean precipitation. Daily mean precipitation in Pontianak was $7.85 \mathrm{~mm} /$ day. This value is almost the 
same amount as that in Palangkaraya, but Pontianak showed a different precipitation pattern from the pattern of Palangkaraya, as shown in Figure 3. Pontianak had two dry periods (using the same definition as in Palangkaraya, daily mean $<5 \mathrm{~mm} /$ day), one was from early February to late March, and the other was from early August to mid August. This precipitation pattern or two dry season pattern is also a typical precipitation pattern in Indonesia, found in northern Sumatra [24]. In Pontianak, the winter dry season is relatively longer but wet for two periods in mid February ( $7 \mathrm{~mm} /$ day) and mid March $(6$ $\mathrm{mm} /$ day), as shown in Figure 3. Due to this higher precipitation tendency, fires were not so active in the winter dry season. The summer dry season period in Pontianak was only $2 / 3$ month and was shorter than three months in Palangkaraya. However, Pontianak also had a strong dry period ( $1 / 3$ month with $2 \mathrm{~mm} /$ day) in early August. Thus, active fires in Pontianak mainly occurred in the short summer dry season and from early to mid August.

\subsection{Fire Prone Areas and Peatland}

In this paper, four province borders in Kalimantan and one country border with Malaysia, defined by the side of a $0.5^{\circ}$ grid cell are shown by dotted lines in Figure 4 for convenience. The total number of cells in the four provinces was 225, comprising 64 for West, 66 for Central, 82 for East and 16 for South Kalimantan. To identify prone areas and to discuss fire activity in Kalimantan in detail, we defined five local regions inside three provinces, excluding East Kalimantan. They were "MRP+" (17 cells including 6 cells from South Kalimantan) in Central and South Kalimantan, "Sampit" (29 cells) in

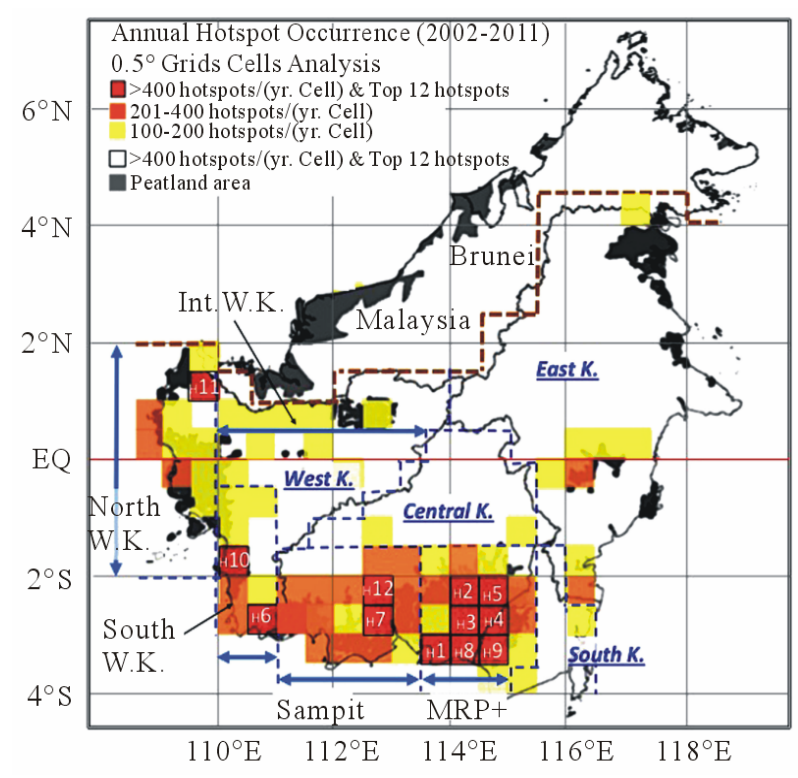

Figure 4. Four provinces, five local areas, and fire prone areas in Kalimantan, 2002-2011.
Central Kalimantan, "North West Kalimantan" (A subset of West Kalimantan, North W.K. for short here after) (24 cells), "South West Kalimantan" (South W.K.) (12 cells), and "Interior West Kalimantan" (Interior W.K.) (26 cells), as shown in Figure 4.

Fire prone areas $(>100$ hotspots $/(y r . c e l l)=0.033$ hotspots $/\left(\mathrm{yr}_{\mathrm{km}} \mathrm{km}^{2}\right)$ in the recent 10 -year interval are highlighted by colors in Figure 4. Many of them are located in the above-mentioned five local regions or coastal peatland areas. Among them, 12 cells showed a very high hotspot density ( $>400$ hotspots/(yr.cell)). They were named H1, H2, H3, etc. in descending order of hotspot density.

The 7 highest hotspot density cells ( $\mathrm{H} 1, \mathrm{H} 2, \mathrm{H} 3$ - 5, $\mathrm{H} 8$, and H9) were located in MRP+ area and covered most of the MRP area. Another two cells (H7 and H12) were in Sampit areas (north and east side of Sampit). The rest of the cells (H6, H10 and H11) were in West Kalimantan. H6 and H10 were in South W.K. and the lowest, H11, was in North W.K. From these distributions, we may say that most fires in Kalimantan are peatland fires because the top 10 highest hotspot density cells are located in the south coastal peatland areas.

\subsection{Recent Annual Rate of Fire Occurrence vs. Precipitation}

The annual fire occurrence in the whole of Kalimantan, the four provinces and the MRP+ region, during the most recent 10-year period (2002-2011), is shown with stacked bars in Figure 5. The unit of the $Y$-axis in Figure $\mathbf{5}$ is the number of hotspots. The stacked bar graph in Figure 5 shows the number of fires in the five regions, from top to bottom: East-, West-, South-, Central-Kalimantan, and MRP+. Here, note that the number of hotspots in South Kalimantan is smaller than the actual number because almost half of the area (analysis cells) of the western part of South Kalimantan belongs to the $\mathrm{MRP}+$ region (Central Kalimantan) in this paper. To denote this meaning, we put "-” after name of South Kalimantan, as "South-K".

The annual mean numbers of fires in the above regions are shown in the rightmost bar on the bottom line of Figure 5, to the right of the bar for 2011. The annual mean bar graph in Figure 5 showed that the mean number of hotspots in Kalimantan is about 22,900 hotspots/yr., $29.6 \%$ of the fires occurred in MRP+, $62.7 \%$ of the fires occurred in Central Kalimantan and South-Kalimantan, and $30.8 \%$ of the fires occurred in (three regions of) West Kalimantan. Although East Kalimantan Province has the largest land area of the four provinces, there were not many fires here in recent years, as shown in Figure 5. We should, however, note that East Kalimantan experienced severe fires under drought conditions in February and March of 1998 under strong El 


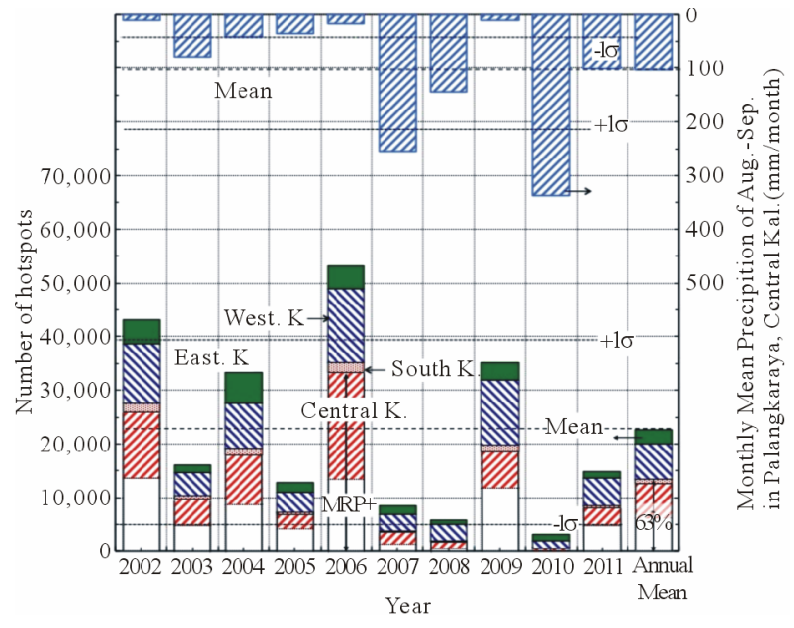

Figure 5. Annual fire occurrence and monthly mean precipitation during Aug.-Sep. in Palangkaraya.

Niño conditions [25].

Fire activity of each year in Figure 5 clearly shows: the number of hotspots in the 10 -year period varied by a factor of about 13.5 between the year with the most fires, 54,000 in 2006, and the year with the fewest, 4000 fires in 2010. Since fire activity in 2002, 2004, 2006 and 2009 was higher than average, we may refer to them as "severe fire years $(>30,000$ hotspots)". Similarly, we call the three years 2003, 2005, and 2011, "average fire years (approximately average number of hotspots)" and the other three years 2007, 2008, and 2010, are referred to as "weak fire years $(<10,000$ hotspots)". The bar graph of the severest fire year, 2006, in Figure 5 showed: the number of hotspots in Kalimantan is about 53,500 hotspots/yr., 33.1\% of the fires occurred in Sampit, 65.9\% of the fires occurred in Central Kalimantan and SouthKalimantan, and $25.8 \%$ of the fires occurred in West Kalimantan.

To explain the different fire activities for each year, the monthly mean precipitation of the driest two months from August to September measured at Palangkaraya Airport were added, using the inversely drawn bars from the top line of Figure 5. We could easily identify that there was a negative correlation between the number of hotspots (fire activity) and amount of precipitation.

\subsection{Recent Seasonal (Every 10-Day Period) Fire Occurrence}

A previous study by Yulianti et al. (2012) [17] has already shown that fires in Kalimantan were most common in the months of August, September, and October. About $85.5 \%$ of the annual hotspot was observed during these three months from August to October. To understand seasonal fire occurrence tendency in detail for various areas in Kalimantan, the same analysis method using 10-day periods in the previous section on the "Dry sea- son" was also applied here.

From Figure 6, we can say that a severe fire season (severe fire: $>1000$ hotspots/(yr.10-day)) in the whole of Kalimantan starts from early August and lasts until early November. A fire peak in late August for the whole of Kalimantan is made by the contribution of active fires in West and Central Kalimantan. The fire season in each of the four provinces in Kalimantan can also be identified from Figure 6.

The two provinces of Central and West Kalimantan show different severe fire periods. The fire season in West Kalimantan started in early August and lasted until early September ( $>500$ hotspots/(yr.10-day)). There was a fire peak in mid to late August (about 1360 hotspots/(10days.yr)). The fire season in West Kalimantan almost coincided with the dry season in August in Pontianak (see Figure 3). Relatively, high fire occurrence (220 - 450 hotspots/(yr.10-day)) in mid September until mid October mainly occurred in the south region of West Kalimantan.

Fires were most severe in Central Kalimantan. The fire season in Central Kalimantan starts in mid August and lasts until early November. A severe fire plateau $(>1300$ hotspots/(yr.10-day)) formed in late August and lasted until mid October. The fire season did not coincide with the dry season from July to September in Palangkaraya (see Figure 2), rather there was one-month difference between the dry season and the fire season. The reason for the one-month difference could be explained by the underground water level, as previously explained by our research group [23].

\subsection{Summary of Recent Fires and El Niño}

To find the relationship between fires (hotspots) and weather conditions, Table 1 was made in descending order of the number of hotspots (150-day ( $\mathrm{DN}=150$ 299) roughly from June to October) of each year. We used NOAA definition of El Niño and La Niña events

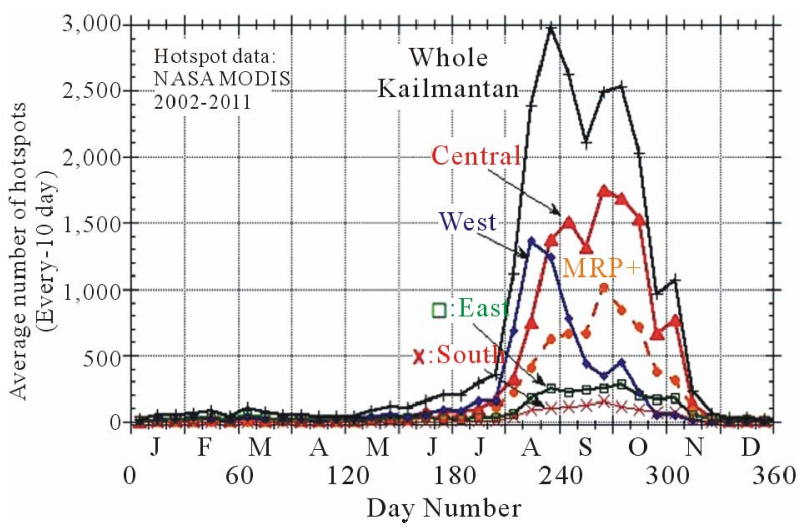

Figure 6. Seasonal (every 10 days) fire occurrence tendencies in Kalimantan. 
Table 1. Fire occurrence and weather conditions in the last ten years (2002-2011).

\begin{tabular}{|c|c|c|c|c|c|c|c|}
\hline \multirow{3}{*}{ Rank by hotspot } & \multirow{3}{*}{ Year } & \multirow{3}{*}{$\begin{array}{l}\text { Sum of num. hotspots } \\
\text { in Kalimantan } \\
\text { Jun.-Oct. (DN:150-299) }\end{array}$} & \multicolumn{5}{|c|}{ Weather conditions } \\
\hline & & & \multicolumn{2}{|c|}{ ENSO } & \multicolumn{3}{|c|}{ Daily mean precipitation (150 days:Jun.-Oct.) mm } \\
\hline & & & El Niño La Niña & $\begin{array}{l}\text { Running 3-month mean } \\
\text { ONI values in } \mathrm{NDJ}^{\mathrm{b}}\end{array}$ & $\begin{array}{c}\text { Average } \\
(\mathrm{A})+(\mathrm{B})) / 2\end{array}$ & (A) Palangka raya & (B) Pontianak \\
\hline 1 & 2006 & 43,383 & Weak El Niño ${ }^{a}$ & 1.0 & 2.4 & 2.0 & 2.8 \\
\hline 2 & 2002 & 41,730 & Moderate El Niño ${ }^{\mathrm{a}}$ & 1.3 & 2.9 & 2.1 & 3.7 \\
\hline 3 & 2009 & 34,078 & Moderate El Niño ${ }^{a}$ & 1.6 & 3.6 & 2.0 & 5.2 \\
\hline 4 & 2004 & 30,801 & Weak El Niño ${ }^{a}$ & 0.7 & 4.7 & 3.0 & 6.3 \\
\hline 5 & 2003 & 15,492 & - & 0.3 & - & 3.6 & - \\
\hline 6 & 2011 & 14,146 & Weak La Niña ${ }^{a}$ & -1.0 & - & 4.5 & - \\
\hline 7 & 2005 & 11,699 & Weak La Niña ${ }^{a}$ & -0.8 & 6.6 & 2.2 & 11.0 \\
\hline 8 & 2007 & 7,478 & Moderate La Niña ${ }^{a}$ & -1.4 & 10.1 & 11.5 & 8.6 \\
\hline 9 & 2008 & 4,722 & - & -0.7 & 7.6 & 4.8 & 10.3 \\
\hline 10 & 2010 & 2,136 & Strong La Niña ${ }^{a}$ & -1.5 & 12.7 & 13.8 & 11.6 \\
\hline Average & & 20,567 & & -0.1 & 6.3 & 5.0 & 7.4 \\
\hline
\end{tabular}

${ }^{\mathrm{a}}$ Defined by NOAA (National Oceanic and Atmospheric Administration); ${ }^{\mathrm{b}}$ ONI: Ocean Nino Index, NDJ: November, December, \& January.

and their SST Anomaly values listed in the middle of Table 1 [26]. Daily mean precipitation values for Palangkaraya and Pontianak were calculated based on daily precipitation values during 150 -day from $\mathrm{DN}=150$. The average values of the two places are also listed in Table $\mathbf{1}$, because this could show dry conditions in West and Central Kalimantan.

From Table 1, severe fire years, 2002, 2004, 2006, and 2009, had more than 30,000 hotspots under the dry conditions arising from the El Niño event with ONI (Ocean Nino index) values in NDJ greater than +0.7 . We could also easily identify a negative correlation between the number of hotspots (fire activity) and the daily mean precipitation values, especially the average value of the two places in Table 1. On the contrary, under Moderate La Niña events or wet conditions, fire activity became very weak $(<10,000$ hotspots).

\subsection{Seasonal and Spatial Fire Occurrence under El Niño Conditions}

To understand seasonal fire activity, a total of 15 of 10 -day seasons from early June $(\mathrm{DN}=150)$ to late October were used, except for 2006 when a total of 17 seasons were used, until mid November. Daily MODIS hotspot and precipitation data were accumulated every 10-day from early June to evaluate fire activity and rainfall conditions in individual seasons from early June to late October. The accumulated number of hotspots for every 10-day was then divided by 10 (days) to show the average daily fire occurrence for each of the seasons. On the other hand, the accumulated precipitation values for every 10-day was accumulated again from early June to late October to make a so-called accumulated precipitation curve. Dry conditions or droughts could easily be recognized by checking the slope of the accumulated precipitation curves.

A total of six areas located in Central, East and West Kalimantan (W.K. for short here after) were selected to understand spatial fire activity during the 15 seasons. The three areas in W.K. were North, Interior and South W.K. The two areas in Central Kalimantan were MRP+ (including the western part of the South Kalimantan province) and Sampit. The last one was East Kalimantan province. "South-Kalimantan" and "Interior Central Kalimantan" are not included in the following analysis, for simplicity, as the number of hotspots for both places were relatively small, and to avoid misunderstanding the result for "South Kalimantan" (only the eastern part of South Kalimantan Province).

In Table 2, fire activities in six areas of each El Niño year are summarized using the total number of hotspots during the 150 days from early June to late October, except for 2006 where 170 days until mid November are used. From Table 2, 2006 was the severest fire year for most areas except North W.K. and East Kalimantan. MRP+ has the largest number of hotspots. Sampit followed MRP+, but there was 3.45 times difference between 17,421 in 2006 and 5052 in 2009. After these two areas, South W.K. followed them. These three areas of MRP+, Sampit and South W.K. cover most of the coastal peatland in Kalimantan and were responsible for about $70 \%$ of hotspots on average. 
Table 2. Summary of fire activities (hotspot) in six areas under El Niño conditions.

\begin{tabular}{cccccccc}
\hline \multirow{2}{*}{ Rank } & \multirow{2}{*}{ Year/period } & \multicolumn{2}{c}{ Central Kalimantan } & \multicolumn{3}{c}{ West Kalimantan } & East Kalimantan \\
\cline { 3 - 6 } & & MRP+ & Sampit & North & South & Int. & 3667 \\
\hline 1 & 2006 Jun.-Nov. & 13,191 & 17,421 & 3543 & 5982 & 3865 & 3884 \\
2 & 2002 Jun.-Nov. & 13,105 & 11,137 & 2715 & 4555 & 3699 & 3042 \\
3 & 2009 Jun.-Nov. & 11,486 & 5,052 & 4142 & 4221 & 3234 & 4208 \\
4 & 2004 Jun.-Nov. & 8,031 & 6,816 & 1824 & 2937 & 3538 & 14,801 \\
& Sum & 45,813 & 40,426 & 12,224 & 17,695 & 14,336 & 10.2 \\
\hline
\end{tabular}

\subsubsection{Seasonal Fire Occurrence in $\mathbf{2 0 0 9}$}

Seasonal fire occurrences in the above-mentioned six areas located in Central, East, and W.K. are shown in Figure 7 using different lines with different symbols. The average daily number of hotspots in every 10-day season from early June $(\mathrm{DN}=150)$ was used here to identify fire seasons and to discuss the relationship with precipitation values in Figures 2 and 3. The spatial distribution of the six areas in Figure 7 can be found in Figure 4. The accumulated precipitation in every 10-day season from early June is also shown in Figure 7, by inverting the $Y$-axis. The two curves found in the top part of Figure 7 are made from precipitation data measured at Palangkaraya and from Pontianak data, as in Figures 2 and $\mathbf{3}$. Units for the $Y$-axis and inversed $Y$-axis in Figure 7 were hotspots/day (average daily number of hotspots) and $\mathrm{mm}$ for accumulated precipitation from $\mathrm{DN}=150$ respetively. From these accumulated precipitation curves for Palangkaraya and Pontianak, the drought period could easily be found by checking the horizontal gradient of the accumulated curve. Thus, accumulated precipitation curves could explain fire activity in the MRP+ area and North W.K. From this weather point of view, hotspot curves for the MRP+ area and North W.K. were illustrated using thick lines and two different symbols ( for $\mathrm{MRP}+, \boldsymbol{\Delta}$ for North W.K.) in Figure 7.

Firstly, we selected 2009 because it was the third severest fire year for MRP+ and the fourth severest fire year for North W.K. (West Kalimantan), but both areas had highest daily number of hotspots, with 297 hotspots/ day in MRP+ in late September and 150 hotspots/day in North W.K. in early August. The severest fire occurrence among the El Niño years of 2002, 2004, 2006 and 2009 could be partially explained by the long duration of the drought conditions, which started in early July, and the lowest accumulated rainfall by late September, of 100 $\mathrm{mm}$ (see Figure 7).

The fire peak for North W.K. in 2009 was short, only in early August with a daily average fire occurrence of about 150 hotspots/day (the highest peak of the recent decade). This fire peak occurred just after the short drought from early July and coincided with the dry season in North W.K. (see Figures 3 and 7). After this peak, the number of hotspots decreased to 67 hotspots/ day and the precipitation to less than $10 \mathrm{~mm} /$ day during early and mid August. A fire peak for interior W.K. was also found in early August, with about 110 hotspots/day, but only lasted until mid August. South W.K. showed a different trend compared to the other two areas in W.K. Namely, South W.K. had a small fire peak in mid September with about 90 hotspots/day but the fire period was more than two months, from early August to early October. This longer fire period indicates that the precipitation pattern for South W.K. could be different from that of other areas in North and Interior W.K.

The fire peak and period for the MRP+ area were quite different from those in the three areas in W.K. In 2009, a fire peak for MRP+ appeared in late September with about 300 hotspots/day (the highest peak of the recent decade). Long drought conditions from around early July may make this a severe fire condition, when a very dry thick layer of peat arose from the rainless conditions. A severe fire period with more than 100 hotspots/day lasted one and 1/3 month, from early September to early October. The fire trend in Sampit area was almost the same, but the fires were not as active as those of MRP+. A fire peak for Sampit occurred in early October with only about 120 hotspots/day. However, Sampit area had the largest fire peak (around 420 hotspots/day, the highest peak of the last decade in the whole of Kalimantan) in mid October in 2006. This unique trend in Sampit suggests that the Sampit area may belong to another precipitation or climate zone.

To fight against these severe fires in MRP+ and W.K. areas, we would like to highlight the small number of fires in June and July as shown in Figure 7. In North W.K., fires (around 20 hotspots/day) already started in early and mid-June. Fires from late July (around 30 hotspots/day) could make the highest peak for North W.K., as shown in Figure 8(c). In MRP+ area, fires 


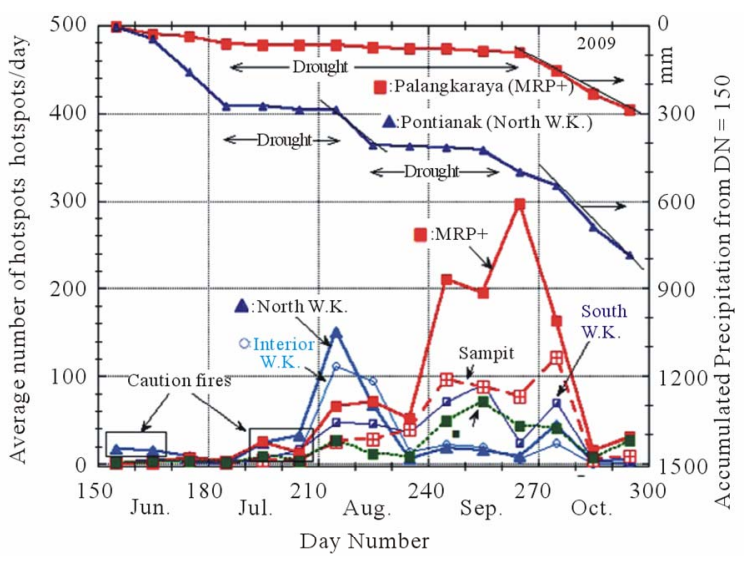

Figure 7. Seasonal fire occurrence and accumulated precipitation from June in 2009.

indicated by around 30 hotspots/day were observed in mid July. Such pre-dry and early season fires may reflect peat and vegetation conditions as fuel for a fire. In other words, a peat and vegetation fire could only start by consuming dry peat and dry vegetation. We should thus pay more attention to these pre-dry and early dry season fires. It could provide a means of fire prevention against Kalimantan fires. We would like to call them "caution fires" to promote the idea of developing new measures against severe peat fires.

\subsubsection{Seasonal Fire Occurrence in 2006}

2006 was the severest fire year for most areas except for North W.K. and East Kalimantan. Sampit showed the highest total number of hotspots, at 17,421 during the 170-days from June to November, as shown in Table 2. In addition, Sampit had highest two daily numbers of hotspots, 418 in mid October and 398 hotspots/day in early November. To analyze seasonal fire occurrence in 2006, Figure 9 shows fire activity from early June to mid November, with a similar figure format to Figure 7.

The two accumulated precipitation curves in the top part of Figure 9 show the longest drought condition, more than 4-months from early July to mid November in Palangkaraya $(\mathrm{MRP}+)$ and lowest accumulated rainfall values of $200 \mathrm{~mm}$ in early September in Pontianak (North W.K.). This means that both areas were drier than other years, which resulted in the worst fire damage.

The fire peak for North W.K. in 2006 was short, only in mid August with a daily average fire occurrence of about 140 hotspots/day (second highest peak of the recent decade). This fire peak occurred during the drought from late July and coincided with the dry season in North W.K. (see Figures 3 and 9). After this peak, the number of hotspots decreased to 20 hotspots/day under drought conditions. This makes us consider another factor, in addition to precipitation, to explain fire activity. A fire peak for interior W.K. was also found in mid August with

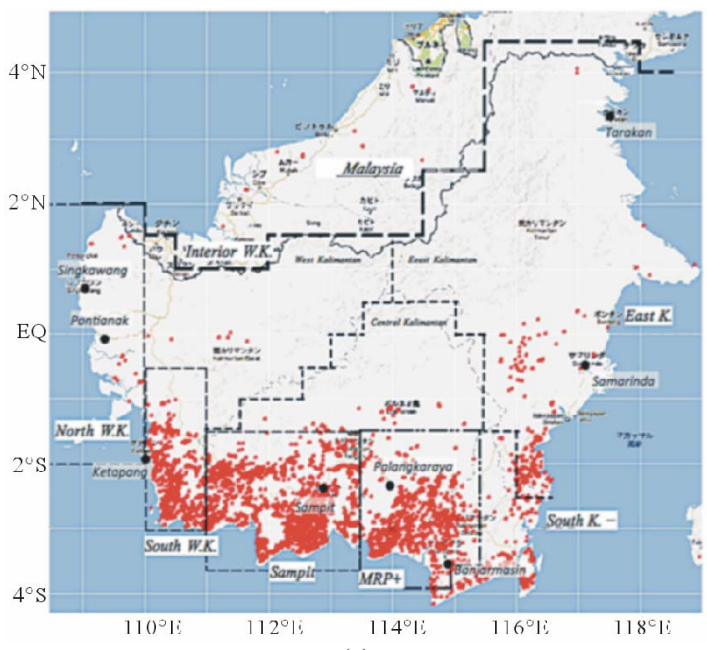

(a)

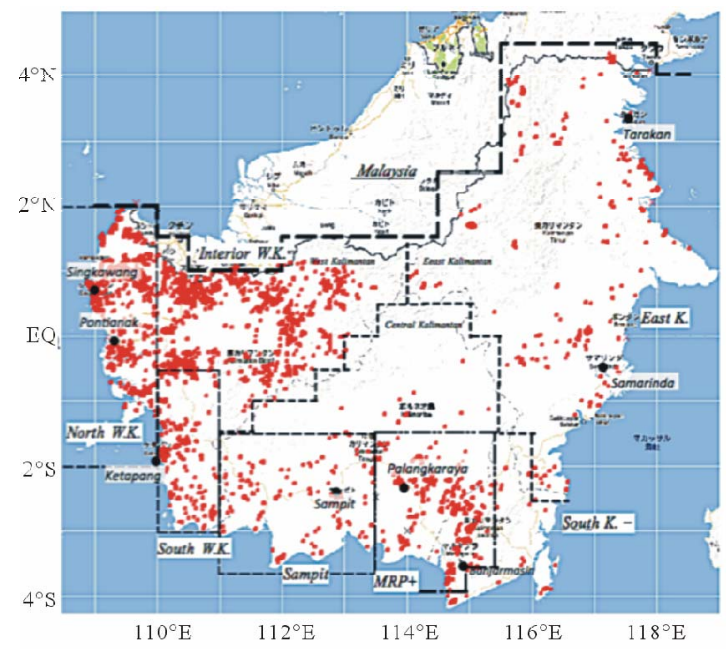

(b)

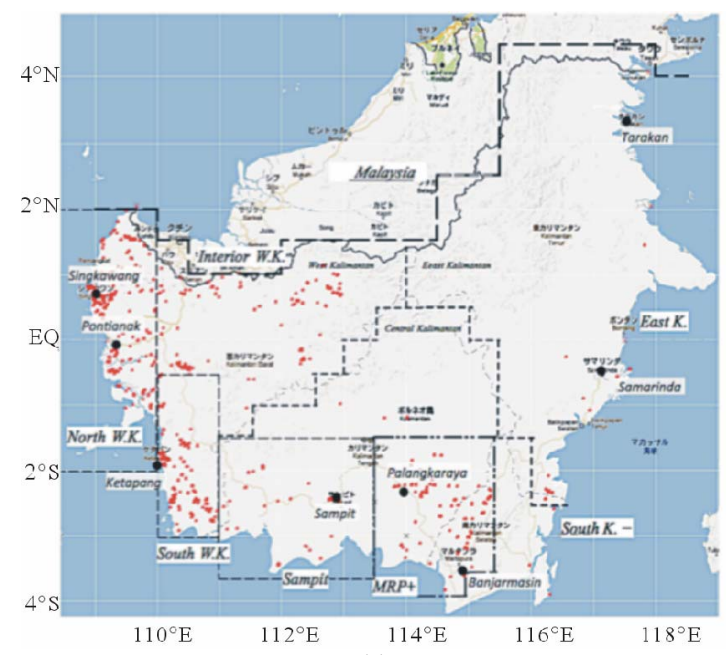

(c)

Figure 8. Three typical fire distributions in Kalimantan. (a) Typical severe fire distribution in mid October (2006); (b) Typical West Kalimantan fire distribution in early August (2009); (c) Typical pre-dry season (caution) fire distribution in late July (2009). 


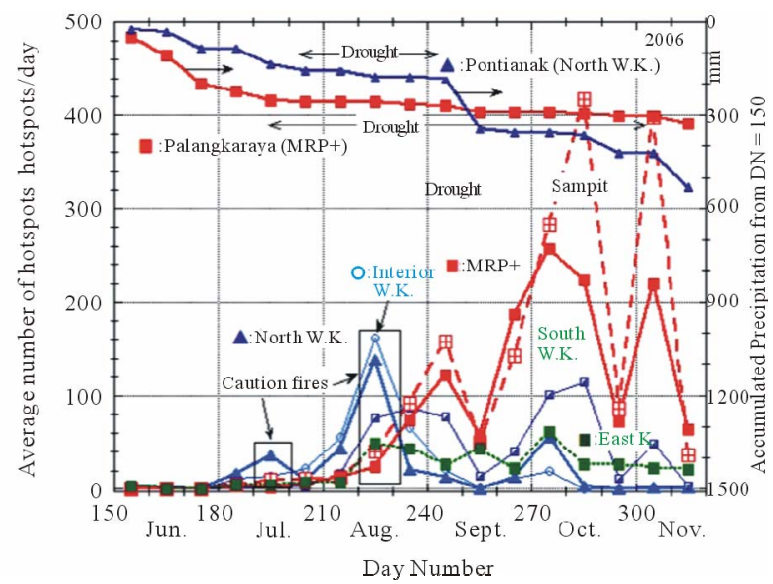

Figure 9. Seasonal fire occurrence and accumulated precipitation from June in 2006.

about 160 hotspots/day (highest peak of the recent decade). After this peak, the number of hotspots decreased to 65 hotspots/day. South W.K. showed two fire periods with around 100 hotspots/day. The first fire period was from mid August to early September. The second one was from early to mid October. The small number of hotspots in mid September can be partially explained by about $15 \mathrm{~mm} /$ day precipitation from early September observed in Pontianak.

The fire peak and period for MRP+ and Sampit area were quite different from other three areas in W.K. In 2006, the fire peak for MRP + appeared in early October with about 260 hotspots/day (the second highest peak of the recent decade). The long duration of drought conditions from around mid July may make this a severe fire condition. A fire peak shift from late September in 2009 to early October in 2006 ( $1 / 3$ month difference) could be partially explained by the shift of the onset of drought from early July in 2009 to mid July in 2006 (1/3 month difference). In addition, a small number of hotspots (about 60 hotspots/day) in mid September could be explained by the above-mentioned September precipitation in Pontianak or the wet conditions.

In a similar manner, precipitation trends may explain Sampit's highest fire peak in mid October in 2006. It is notable that there was large difference between the final values of the accumulated precipitation curves for Pontianak in Figures $\mathbf{7}$ and 9, showing around $80 \mathrm{~mm}$ (totally $800 \mathrm{~mm}$ rainfall from $\mathrm{DN}=150$ ) and around 43 $\mathrm{mm}$ (totally $430 \mathrm{~mm}$ rainfall from $\mathrm{DN}=150$ ) in 2009 and 2006, respectively. On the other hand, precipitation curves for Palangkaraya in Figures $\mathbf{7}$ and $\mathbf{9}$ showed around $30 \mathrm{~mm}$ (totally $300 \mathrm{~mm}$ rainfall from $\mathrm{DN}=150$ ). These lower precipitation or longer drought conditions in both Pontianak and Palangkaraya suggest that the dry area in 2006 was wider than that in 2009. These precipitation conditions could explain why there was more se- vere fire activity in 2009, including fires in Sampit. Under the very dry conditions in 2006, Sampit fires lasted until early November.

In 2006, caution fires for North W.K. could also be found in mid July, as shown in Figure 9. Caution fires for MRP+ were not so clear due to the delayed onset of the drought (from around early July). However, caution fires could still be found in mid and late August.

\subsection{Typical Fire Distributions in El Niño Years}

In Figure 8, three typical fire distributions in El Niño years are shown. Figure 8(a) shows the fire distribution during the severest fire period in mid October ( $D N=280$ 289) in 2006, Figure 8(b) shows the distribution of fires in August (dry season for north area of W.K.): early August $(\mathrm{DN}=210-219)$ in 2009, and Figure 8(c) shows the fire distribution in the pre-dry season (caution fires): late July (DN = 200 - 209) in 2009.

Sampit area suffered from the severest fires (total number of hotspots exceeded more than 17,000) in the most recent 10-year (2002-2011). Seasonal fire peaks appeared in mid October under the long drought condition from early July (see Figure 9). The total number of hotspots in mid October was 4178 (418 hotspots/day) and the distribution is shown in Figure 8(a). From Figure 8(a), we note that most fires were distributed along the coastal peatland in southern Kalimantan. These severe fires on peatland in Central Kalimantan during the last period of the dry season could become very active due to the very low level of ground water, as explained by Putra and Hayasaka (2011) [22]. In 2006, drought conditions lasted for more than 4-months from mid July to early November. Under these long-lasting dry conditions, peat fires could continue by smoldering under the ground or in peat layer. Thus, peat fire cannot be suppressed as described in Usup et al. (2004) [27]. 2006 fires were a good example because they showed us that peat fires could remain active until heavy rain comes or even until November.

Typical dry season fires for West Kalimantan (including North, Interior, and South W.K.) occurred early in August ( $\mathrm{DN}=210-219)$ in 2009 (see Figure 7). The total number of hotspots in early August was 3094 and they were distributed like in Figure 8(b). From Figure 8(b), you can see a high density of fires on coastal and interior peatland, and in mountain areas (deforestation fires) along the border with Malaysia. Fires in MRP+ already became active from early August.

Pre-dry and early dry season fires in late July were plotted with a dot in Figure 8(c) (see also Figure 7). From Figure 8(c), it is clear that most fires were located on coastal peatland areas in W.K., the inland peatland area in Interior W.K., and in the MRP+ area (see Figures 
1 and 4).

\section{Acknowledgements}

The authors thank Minnie Wong of the University of Maryland, USA, for providing the MODIS hotspot data. Thanks to Hidenori Takahashi of Hokkaido Institute of Hydrology-climate of Hokkaido University for precipitation data from West Kalimantan. This research was partially supported by the JST-JICA Science and Technology Research Partnership for Sustainable Development (SATREPS) project on "Wild Fire and Carbon Management in Peat-Forest in Indonesia".

\section{REFERENCES}

[1] J. G. Goldammer and B. Seibert, "Natural Rain Forest Fires in Eastern Borneo during the Pleistocene and Holocene," Naturewissenschaften, Vol. 76, No. 11, 1989, pp. 518-520. doi:10.1007/BF00374124

[2] D. O. Fuller and K. Murphy, "The ENSO-Fire Dynamic in Insular Southeast Asia," Climatic Change, Vol. 74, No. 4, 2006, pp. 435-455. doi:10.1007/s10584-006-0432-5

[3] M. J. Wooster, G. L. W. Perry and A. Zoumas, "Fire, Drought and El Niño Relationship on Borneo (Southeast Asia) in the Pre-MODIS Era (1980-2000)," Biogeosciences, Vol. 9, No. 1, 2012, pp. 317-340. doi:10.5194/bg-9-317-2012

[4] K. MacKinnon, G. Hatta and A. Mangalik, "The Ecology of Kalimantan," Oxford University Press, Oxford, 1997.

[5] Ministry of Forestry Indonesia, "Forest Statistic in 2010," Directorate General of Forestry Planology, Jakarta, 2011. http://www.dephut.go.id/index.php?q=id/node/8347

[6] J. Miettinen, C. Shi and S. C. Liew, "Influence of Peatland and Land Cover Distribution on Fire Regimes in Insular Southeast Asia," Regional Environmental Change, Vol. 11, No. 1, 2011, pp. 191-201.

doi:0.1007/s10113-010-0131-7

[7] E. I. Putra, H. Hayasaka, H. Takahashi and A. Usup, "Recent Peat Fire Activity in the Mega Rice Project Area, Central Kalimantan, Indonesia," Journal of Disaster Research, Vol. 3, No. 5, 2008, pp. 334-341.

http://www.fujipress.jp/finder/xslt.php?mode=present\&in putfile=DSSTR000300050002.xml

[8] H. Haykiri-Açma, A. Ersoy-Meriçboyu and S. Küçükbayrak, "Combustion Reactivity of Different Rank Coals," Energy Conversion and Management, Vol. 43, No. 4, 2002, pp. 459-465. doi:10.1016/S0196-8904(01)00035-8

[9] A. Hoscilo, S. E. Page, K. J. Tansey and J. O. Rieley, "Effect of Repeated Fires on Land-Cover Changes on Peatland in Southern Central Kalimantan, Indonesia, from 1973 to 2005," International Journal of Wildland Fire, Vol. 20, No. 4, 2011, pp. 578-588. doi:10.1071/WF10029

[10] A. Hooijer, M. Silvius, H. Wosten and S. Page, "Peat$\mathrm{CO}_{2}$ : Assessment of $\mathrm{CO}_{2}$ Emission from Drained Peatlands in SE Asia," Delft Hydraulics Report Q3943, 2006. http://www.wetlands.org/LinkClick.aspx?fileticket=NYQ UDJ15zt8=\&tabid $=56$
[11] F. Siegert, H.-D. V. Boehm, J. O. Rieley and S. E. Page, J. Jauhiainen, H. Vasander and A. Jaya, "Peat Fires in Central Kalimantan, Indonesia: Fire Impacts and Carbon Release," Proceedings of the International Symposium on Tropical Peatland, Jakarta, 22-23 August 2001, pp. 142-145.

[12] T. Notohadiprawiro, "Mega-Project of Central Kalimantan Wetland Development for Food Crop Production, Belief and Truth," Proceedings of the International Peat Symposium the Spirit of Peatlands, Jyvaskyla, 7-9 September 1998, pp. 14-24.

[13] J. L. Hamada, M. D. Yamanaka, J. Matsumoto, S. Fukao, P. A. Winarso and T. Sribimawati, "Spatial and Temporal Variations of the Rainy Season over Indonesia and Their Link to ENSO," Journal of Meteorological Society of Japan, Vol. 80, No. 2, 2002, pp. 285-310. doi:10.2151/jmsj.80.285

[14] P. Chang, Z. Wang, J. McBride and C. H. Liu, "Annual Cycle of Southeast Asia-Maritime Continent Rainfall and the Asymmetric Monsoon Transition," Journal Climate, Vol. 18, No. 2, 2005, pp. 287-301. doi:0.1175/JCLI-3257.1

[15] R. Dennis, "A Review of Fire Projects in Indonesia (1982-1998)," CIFOR/ICRAF/UNESCO/EC-JRC, 1999. http://www.cifor.org/fire/pdf/pdf20.pdf

[16] K. P. Vadrevu and C. O. Justice, "Vegetation Fires in the Asian Region: Satellite Observational Needs and Priorities," Global Environmental Research, Vol. 15, No. 1, 2011, pp. 65-76.

[17] N. Yulianti, H. Hayasaka and A. Usup, "Recent Forest and Peat Fire Trends in Indonesia, the Latest Decade by Modis Hotspot Data," Global Environmental Research, Vol. 16, No. 1, 2012, pp. 105-116.

[18] A. Langner and F. Siegert, "Spatiotemporal Fire Occurrence in Borneo over a Period of 10 Years," Global Change Biology, Vol. 15, No. 1, 2009, pp. 48-62. doi:0.1111/j.1365-2486.2008.01828.x

[19] BPS (Badan Pusat Statistik), "Trends of the Selected Socio-Economic Indicators of Indonesia," BPS-Statistic Indonesia, Jakarta, 2010.

[20] Wetlands, "Maps of Area of Peatlands Distribution and Carbon Content in Kalimantan," Wetlands InternationalIndonesia Programme, Bogor, 2004.

[21] S. Sabiham, "Studies on Peat in the Coastal Plains of Sumatra and Borneo," Southeast Asian Studies, Vol. 26, No. 3, 1988, pp. 308-335. http://ci.nii.ac.jp/naid/110000200489

[22] J. Jaenicke, J. O. Rieley, C. Mott, P. Kimman and F. Siegert, "Determination of the Amount of Carbon Stored in Indonesian Peatlands," Geoderma, Vol. 147, No. 3-4, 2008, pp. 151-158. doi:10.1016/j.geoderma.2008.08.008

[23] E. I. Putra and H. Hayasaka, "The Effect of the Precipitation Pattern of the Dry Season on Peat Fire Occurrence in the Mega Rice Project Area, Central Kalimantan, Indonesia," Tropics, Vol. 19, No. 4, 2011, pp. 145-156. doi:10.3759/tropics.19.145

[24] E. Aldrian and R. D. Susanto, "Identification of Three Dominant Rainfall Regions within Indonesia and Their Relationship to Sea Surface Temperature," International 
Journal Climatology, Vol. 23, No. 12, 2003, pp. 14351452. doi:10.1002/joc. 950

[25] F. Siegert and A. A. Hoffmann, "The 1998 Forest Fires in East Kalimantan (Indonesia): A Quantitative Evaluation Using High Resolution, Multitemporal ERS-2 SAR Images and NOAA-AVHRR Hotspot Data," Remote Sensing of Environment, Vol. 72, No. 1, 2000, pp. 64-77. doi:10.1016/S0034-4257(99)00092-9
[26] National Ocean and Atmosphere Administration (NOAA), "El Niño and La Niña Years and Intensities," 2012. http://www.cpc.ncep.noaa.gov/products/analysis_monitor ing/ensostuff/ensoyears.shtml

[27] A. Usup, Y. Hashimoto, H. Takahashi and H. Hayasaka, "Combustion and Thermal Characteristics of Peat Fire in Tropical Peatland in Central Kalimantan," Tropics, Vol. 14, No. 1, 2004, pp. 1-19. doi:10.3759/tropics.14.1 